\title{
IMPROVING THE PROCESS OF ACHIEVING REQUIRED MICROSTRUCTURE AND MECHANICAL PROPERTIES OF 38MNVS6 STEEL
}

\author{
Dominika SIWIEC ${ }^{1}$, Renata DWORNICKA ${ }^{2}$, Andrzej PACANA ${ }^{3}$ \\ ${ }^{1}$ Rzeszow University of Technology, Rzeszow, Poland, EU, d.siwiec@prz.edu.pl, \\ ORCID ID: 0000-0002-6663-6621 \\ ${ }^{2}$ Cracow University of Technology, Cracow, Poland, EU, renata.dwornicka@mech.pk.edu.pl, \\ ORCID ID: 0000-0002-2979-1614 \\ ${ }^{3}$ Rzeszow University of Technology, Rzeszow, Poland, EU, app@prz.edu.pl, \\ ORCID ID: 0000-0003-1121-6352
}

https://doi.org/10.37904/metal.2020.3525

\begin{abstract}
The micro-alloyed steel $38 \mathrm{MnVS6}$ (38MnSiVS5 or 38MnVS5) applied mostly in the automotive industry (for example production of forgings), has a high yield point and relatively good wear resistance. Aim of the study was preliminary to analyse the influence of twice the normalization process of micro-alloyed steel 38MnVS6 on its microstructure and mechanical properties. The normalization process was made in two steps in a pusher furnace PP-300 at temperatures $910^{\circ} \mathrm{C}$ (cooling under the fan $5200 \mathrm{rpm}$ ) and $880{ }^{\circ} \mathrm{C}$ (cooling in open air). The total normalization time was 16200 seconds each time. Yield strength, tensile strength and hardness were analysed. Analysis was occurred based on results of the normalization process of three forgings for use in the automotive industry, ball-shaped and weight $28 \mathrm{~N}$, forged from a temperature of $1250^{\circ} \mathrm{C}$ from micro-alloyed steel $38 \mathrm{MnVS6}$. It has been shown that carrying out two processes for normalizing micro-alloy steel $38 \mathrm{MnVS} 6$ allows achieving its homogeneous and fine-grained microstructure and obtaining better mechanical properties and thus filled the gap regarding the lack of analysis of the impact of the normalization process on 38MnVS6 steel.
\end{abstract}

Keywords: $38 \mathrm{MnVS6}$, mechanical engineering, normalization process, mechanical properties, quality of product

\section{INTRODUCTION}

The dynamic development of industry caused that need for reliable and relatively low-cost production of products has become a key in making the effective actions of enterprises as part of their sustainability development [1-3]. These actions are referred in particular to the minimization of the costs of logistic actions, thermal treatment and realization production process time [4]. As part of these activities particularly important, mainly in the automotive industry [4], is using the micro-alloy steel, for example, 38MnVS6 (38MnSiVS5, previously marked $38 \mathrm{MnVS5}$ ) $[5,6]$, so the medium-carbon-manganese steel $[7,8]$, about an application to controlled cooling from forging temperature. It results among others from content for example $\mathrm{Al}$, Ti or $\mathrm{V}$, which allows the growth of steel strength, without hardening and tempering. Addition, the 38MnVS6 steel has high yield strength and good wear resistance [1,9]. Therefore, it has particularly application to production the automotive components in the form of forgings [10,11], for example crankshafts [12], and also engine pistons, which successfully replace pistons from aluminum-silicon alloy [13]. Using the micro-alloy steel, although that steel needs the mechanical machining constituting approx. $50 \%-60 \%$ of all production costs [4], is allowed to reduce the energy and production costs $[7,11,14]$, for example compared to heat-treated steel or hardened steel by $30 \%$ and $20 \%$ respectively [1]. Also, in the context of reduction of cost by production among others 
forgings made of micro-alloy steel, it is important the fact that when are produced under the right conditions, they do not require normalization. It results from micro additions introduced into steel, which allows creating a homogeneous and fine-grained structure, preventing the growth of recrystallized austenite grains [15]. However, if the need arises to the normalization of micro-alloy steel, which the aim is creating required microstructure and mechanical properties of steel, it anyway this process is less expensive than normalization of the alloy steel [16]. In the context of normalization of the micro-alloy steel, the authors of works $[16,17]$ analysed the mechanical properties and microstructure of normalized micro-alloy steel with including the influence of micro additions, i.e. Nb [17], zirconium and titanium [17]. At work [17] in context of based on the weld, it was shown that as increases holding time at normalization temperature $920^{\circ} \mathrm{C}$, the microstructure of the columnar grain zone (CGZ) is modified from one column grain to one equiaxed grain (both in joint with the addition of $\mathrm{Nb}$ and without the addition of $\mathrm{Nb}$ ). It also was shown, that the mechanical properties have not shown the clear changes with increases holding time at normalization temperature $920{ }^{\circ} \mathrm{C}$, both with the addition of $\mathrm{Nb}$ and without the addition of $\mathrm{Nb}$. Also, for example, with increases holding time at normalization temperature the hardness of weld with $\mathrm{Nb}$ was increased, but the elongation and impact strength have decreased significantly. Whereas at work [16] the influence of zirconium and titanium in connections were analysed, for microstructures and mechanical properties, among others the micro-alloy steel, and it was comparing the results with the low-alloy stainless steels. It was concluded, i.a. the presence of sludge contributes to the improvement of strength and impact strength of steels containing micro-alloy in the heattreated condition. However, though the analyses in the context of normalization of micro-alloy steel it was concluded that not analysed the normalization one of the micro-alloy steel i.e. 38MnVS6 (38MnSiVS5 or $38 \mathrm{MnVS5}$ ) [4], which is mainly used in the automotive industry [10-13]. At the same time, as part of the review of the literature on the subject, it was shown that this steel is an important research area.

The steel 38MnVS6 was analysed for example in terms of machinability [4], elastic properties after the hardening process [18], as well as the influence on its microstructure of the controlled forging and cooling process [1]. For example, at work [12] authors were analysed the steel machinability, by the influence the cutting speed, cutting force and feed speed for flank wear and hardness of TiN coated carbide tool inserts. It was concluded, that machined chips are regular and discontinuous, therefore it was considered that steel machinability is more effective than the alloy steels about the same hardness (i.e. AISI 1405 and AISIS 5140) heat-treated at the same conditions. In turn, at work [1] was analysed the influence of controlled forging and cooling process on the structure of steel, analysed the parameters of the process, value and temperature of strain, and also the cooling speed after forging. It was shown, that the smallest austenite grain is possible to achieve by $70 \%$ strain and at temperature $850{ }^{\circ} \mathrm{C}$ in the final stage of the forging process, while the authors of [18] analysed the elastic properties of steel after the induction hardening process. In the part of analysis, the steel sample was annealed before quenching. The analysis was shown that in effect if annealed the changes of elastic properties were done, where the transverse wave speed was highest than longitudinal wave velocity, and at the same, it was caused the increase in Poisson's ratio about $0.32 \%$. A review of the literature on the subject indicates that so far the analysis of the micro-alloy steel were making, but these analyses did not include double normalization of $38 \mathrm{MnVS} 6$ steel. Therefore, it was concluded that it is a gap, in view of shown importance of micro-alloy steel $38 \mathrm{MnVS} 6$ in the production of products mainly from the automotive industry [4,10-13]. Therefore, the aim of the work was to analysed the influence of double normalization of micro-alloy steel $38 \mathrm{MnVS} 6$ as part of changing its microstructure and mechanical properties. The analysis was made based on research results obtained from enterprise ForgeX Polska Sp. z o.o. localized in Podkarpacie. The research was concerned about double normalization in the context of the pursuit of achieving the required microstructure and mechanical properties of the forgings from micro-alloy steel 38MnVS6.

\section{SUBJECT OF STUDY AND MATERIAL}

The micro-alloy steel $38 \mathrm{MnVS6}$ (38MnSiVS5, before called $38 \mathrm{MnVS5})[5,6]$ is medium-carbon-manganese steel $38 \mathrm{MnVS} 6[8,10]$, which is one of main of unhardened steels [7] about destiny for controlled cooling from 
forging temperature. One of the benefits using micro-alloy steel $38 \mathrm{MnVS} 6$ is the content of micro alloys, for example $\mathrm{V}$ (Table 1), which allows on the growth of steel strength without necessarily hardened and tempered, which in turn off allows reducing the production costs [7,14].

Table 1 Chemical compositions of micro-alloy steel 38MnVS6 [7,9,19]

\begin{tabular}{|c|c|c|c|c|c|c|c|c|c|}
\hline Component & $\mathbf{C}$ & $\mathbf{S i}$ & $\mathbf{M n}$ & $\mathbf{P}$ & $\mathbf{S}$ & $\mathbf{C r}$ & $\mathbf{V}$ & $\mathbf{N}$ & $\mathbf{V}$ \\
\hline Content [\%] & $\begin{array}{c}0.34- \\
0.41\end{array}$ & $\begin{array}{c}0.15- \\
0.80\end{array}$ & $\begin{array}{c}1.20- \\
1.60\end{array}$ & $<0.025$ & $\begin{array}{c}0.02- \\
0.06\end{array}$ & $<0.30$ & $\begin{array}{c}0.08- \\
0.20\end{array}$ & $\begin{array}{c}0.01- \\
0.02\end{array}$ & $\begin{array}{c}0.08- \\
0.20\end{array}$ \\
\hline
\end{tabular}

The steel 38MnVS6 because i.a. has high yield strength and good wear resistance [1,9] has applies to the production of hot forged products from the automotive industry $[9,12,14]$ for example car forgings [10] which are the subject of this work. The subject of the study were three forgings with a ball shape and weight $28 \mathrm{~N}$, forged from temperature $1250^{\circ} \mathrm{C}$ from $38 \mathrm{MnVS} 6$ steel, which choice resulted from the need of achieving their required mechanical properties (Figure 1).

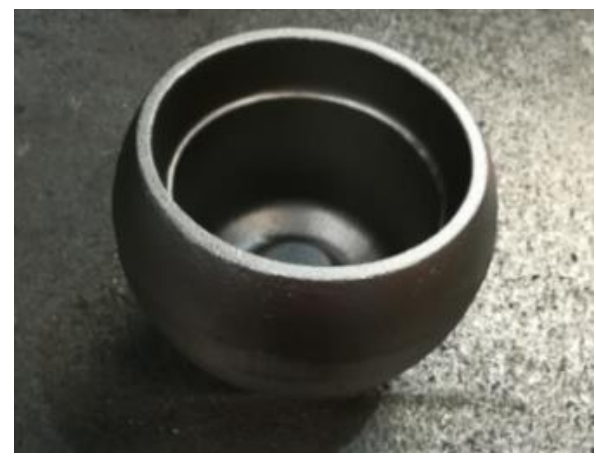

Figure 1 An example of forging after shot blasting process (source: own study)

The aim of making the double normalization process was to achieve the required microstructure and mechanical properties of $38 \mathrm{MnVS} 6$ steel, which are presented in Table 2.

Table 2 Set of required mechanical properties

\begin{tabular}{|c|c|c|c|c|}
\hline Hardness [HBW] & $\begin{array}{c}\text { Yield Strength Re } \\
\text { [MPa] }\end{array}$ & $\begin{array}{c}\text { Tensile Strength } \\
\mathbf{R m}[\mathrm{MPa}]\end{array}$ & Elongation A5 [\%] & KVmin [J/cm2] \\
\hline $4.51-3.97$ & $\geq 450$ & $600-770$ & $\geq 15$ & 27 \\
\hline
\end{tabular}

As the part of selected subject of the work, it was analysed main, selected mechanical properties, ie. yield strength (Re, MPa), tensile strength (Rm, MPa) and hardness (HBW). During the measurements it were used, among others testing machine ZWICK BZ200/SN6S-M and impact hammer Charpy LabTest CHK300J. From three pieces of samples with dimensions $105 \mathrm{~mm} \times 105 \mathrm{~mm}$, a bite of material from protruding material from micro-alloy steel $38 \mathrm{MnVS6}$ (rolled steel mill material) was cut. The bit of material was obtained in effect material overheating in a gas furnace at temperature $1250^{\circ} \mathrm{C}$ and forging by a five-ton hammer, which was cooling was on free air. Next, the bit of material was heated in the gas furnace at temperature $1250{ }^{\circ} \mathrm{C}$, in a matrix on the five-ton hammer, receiving forging with a ball shape and weight $28 \mathrm{~N}$, which was cooling was on free air. Then, forgings were double normalized in a pusher furnace PP-300. In the first step of normalization, the furnace was heated to $910^{\circ} \mathrm{C}$, and cooling took place with a fan about parameters $5200 \mathrm{rpm}$. In the second step, three normalized forgings were normalized again (i.e. double normalized), where the furnace was heated to $880^{\circ} \mathrm{C}$, and cooling was on free air. Total time of normalization both in the first and second steps was 16200 seconds (i.e. $4 \mathrm{~h} 30$ minutes) by moving the tape every 1800 seconds (i.e. 30 minutes). The results achieved of selected mechanical properties after each step of the machining stage were analysed. 


\section{RESULTS}

The set of the mechanical properties selected for analysis after the double normalization process of three forgings from $38 \mathrm{MnVS} 6$ steel is shown in Table 3.

Table 3 The set of selected mechanical properties

\begin{tabular}{|c|c|c|c|c|}
\hline \multirow{2}{*}{ Step of process } & \multicolumn{3}{|c|}{ Mechanical properties } & \\
\cline { 2 - 5 } & $\begin{array}{c}\text { Sample } \\
\text { number }\end{array}$ & $\mathbf{R e}$ (MPa) & Rm (MPa) & HBW \\
\hline Material from the smelter & $1-2-3$ & $578-568-593$ & $822-821-852$ & $234-249-241$ \\
\hline A bite after forging & $1-2-3$ & $530-509-521$ & $867-808-817$ & $266-252-252$ \\
\hline $\begin{array}{c}\text { Forging without heat } \\
\text { treatment }\end{array}$ & $1-2-3$ & $512-514-505$ & $825-833-825$ & $249-249-252$ \\
\hline $\begin{array}{c}\text { Forging after normalization } \\
\text { Forging after normalizing } \\
\text { twice }\end{array}$ & $1-2-3$ & $413-478-424$ & $751-752-756$ & $224-224-217$ \\
\hline \begin{tabular}{c} 
Fice \\
\hline
\end{tabular} & $1-2$ & $480.59-473.5-463.01$ & $733.83-767.38-741.08$ & - \\
\hline
\end{tabular}

a)

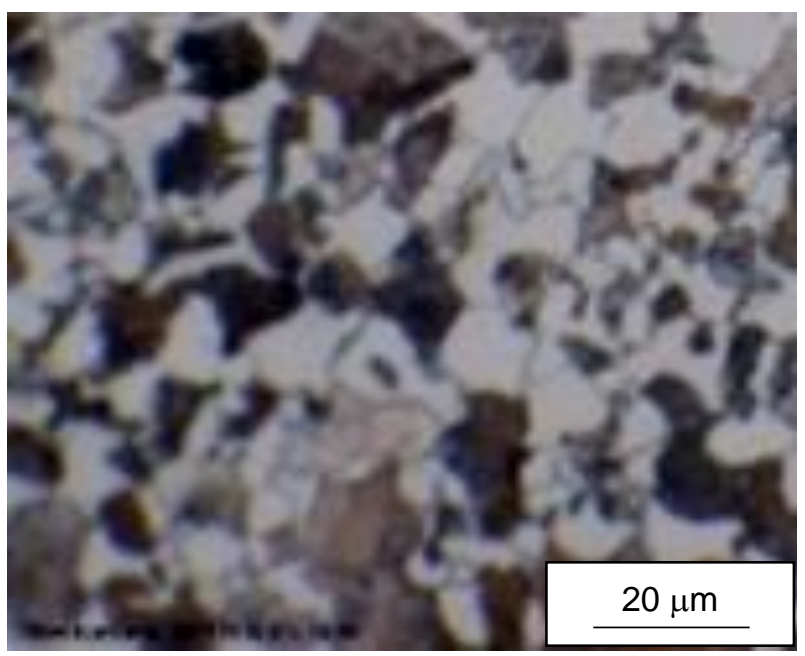

b)

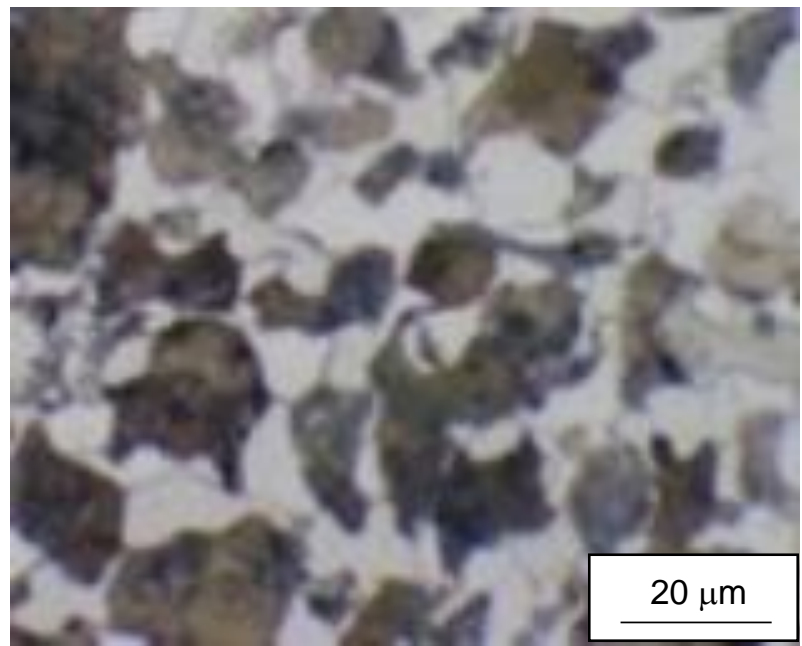

Figure 2 A comparison of the microstructure of micro-alloy steel 38MnVS6 in zoomed 500, digestion: nital, a) before double normalization, b) after double normalization (source: own study)

After analysis the values of selected mechanical properties for three samples cut from initial material from $38 \mathrm{MnVS6}$ steel (i.e. material from the smelter), and also a bite after forging and forging without heat treatment, incompatibilities meeting properties of tensile strength, which were exceeded $770 \mathrm{MPa}$ were shown. Next, it was demonstrated that made one time of normalization process allow achieved only selected mechanical properties, resp. yield strength and hardness. Despite this, the yield strength was not achieved yet, which for samples about numbers 1 and 3 were respectively equal $431 \mathrm{MPa}$ and $424 \mathrm{MPa}$. In turn, it was shown that made double normalization process was effective and allows achieved all intended mechanical properties. Additional, during analyses the microstructures of 38MnVS6 steel was analysed before and after double normalization process (Figure 2) by using a metallographic optical microscope OLYMUS PMG 3 . It was concluded that the double normalization process was allowed achieved homogeneous, fine-grained perliteferritic microstructure. 


\section{CONCLUSION}

Making the right actions of enterprises in part of their sustainable development is a necessary area in pursuit of continuous improvement [3,20-22]. One of the key actions of enterprises from the automotive industry is the right machining steel under to achieving its need properties. Therefore, the aim of the work was preliminary analysed the influence of the double normalization process of micro-alloy steel $38 \mathrm{MnVS} 6$ on its microstructure and mechanical properties. Analysis was made based on results of the normalization process, regarding normalization three forgings about ball shape and weight $28 \mathrm{~N}$, forged from a temperature of $1250{ }^{\circ} \mathrm{C}$ from micro-alloy steel 38MnVS6, having applications in the automotive industry. The selected properties were analysed, i.e. hardness, yield strength and tensile strength. It has been shown that carrying out two processes for normalizing micro-alloy steel 38MnVS6 allows achieving its homogeneous and fine-grained microstructure and obtaining better mechanical properties. It was demonstrated the influence double normalization process of microstructure and mechanical properties of $38 \mathrm{MnVS} 6$ steel, and thus the gap was filled regarding the lack of analysis of the impact of the normalization process on 38MnVS6 steel. The applied improvement procedure may be of interest for other industry branches i.a. in steel industry [23-25], corrosion resistance [26,27] coatings [28] and bioceramics [29-31] as well as in management [32-34].

\section{REFERENCES}

[1] DING, J., ZHANG, Y.J. and CHEN, Y.B. Effect of controlled forging and cooling process on structure of $38 \mathrm{MnVS5}$ microalloyed steel. Transactions of Materials and Heat Treatment. 2006. vol. 27, pp. 35-38.

[2] LARRUCEA, X., MOFFIE, M., ASAF, S. et al. Towards a GDPR compliant way to secure European cross border Healthcare Industry 4.0. Computer Standards \& Interfaces. 2020, vol. 69, pp. 1-7.

[3] PACANA, A., CZERWINSKA, K. and BEDNAROVA, L. Comprehensive improvement of the surface quality of the diesel engine piston. Metalurgija. 2018. vol. 58, pp. 329-332.

[4] EBRAHIMI, A. and MOSHKAR, M.M. Study of machinability in boring operation of microalloyed and heat-treated alloy steels. Materials Science and Engineering: A. 2007. vol. 460-451, pp.314-323.

[5] SU, J., QIU, X., XING, F. and RUAN, Y. Effect of Preheating Temperature on Microstructure and Properties of 42CrMo4/38MnVS6 Heterogeneous Laser Welded Joint. Metals. 2019, vol. 9, art. 870.

[6] Supply specification steels for quenching and tempering, steels for induction hardening, ferritic-pearlitic (AFP) [online]. [viewed 28.05.2020]. Available from: https://www.epoptavka.cz/files/soubor 66be3364.pdf

[7] GU, S.-D., ZHANG, L.-W., RUAN, J.-H., ZHOU, P.-Z. and ZHEN, Y. Constitutive Modeling of Dynamic Recrystallization Behavior and Processing Map of 38MnVS6 Non-Quenched Steel. J. Mater. Eng. Perform. 2014. vol. 23, pp. 1062-1068.

[8] OPELA, P., SCHINDLER, I. and KAWULOK, P. New Model Predicting Flow Curves in Wide Range of Thermomechanical Conditions of 38MnVS6 Steel. In METAL 2016: $25^{\text {th }}$ Int. Conf. on Metallurgy and Materials. Ostrava: TANGER, 2016, pp. 458-463.

[9] SCURRIA, M., EMRE, S., MOELLER, B., WAGENER, R. and MELZ, T. Evaluation of the Influence of MnS in Forged Steel 38MnVS6 on Fatigue Life. SAE Int. J. Engines. 2017. vol. 10, pp. 366-372.

[10] KIRUMA, T. and KUREBAYASHI, Y. Niobium in microalloyed engineering steels, wire rods and case carburized products. In Proc. of Int. Symposium Niobium. Orlando: United States, 2001, pp. 801-819.

[11] SHEN, P., YANG, Q., ZHANG, D., YANG, S., FU, J. The effect of tellurium on the formation of MnTe-MnS composite inclusions in non-quenched and tempered steel. Metals. 2018, vol. 8, art. 639.

[12] STEINMETZ, H., REINHARDT, R., TROMMER, F. Aufgleitendes Reibschweißen eröffnet neue Anwendungsgebiete im Automobilbau. In Conference: 19th Erfahrungsaustausch Reibschweißen. München: At SLV, 2011, pp. 1-3.

[13] VIDHYASAGAR, M., BALACHANDRAN, G. An Assessment of Ladle Furnace Steel-making Reactions in an Aluminium-Killed 38MnS6 Steel. Trans. Indian Inst. Met. 2020, vol. 73, pp. 479-495.

[14] NIU, D., ZHANG, J., XIONG, P., HAO, G., LIU, S., GUO, W. High temperature fatigue and oxidation characteristics of forged steel piston materials. Engineering Failure Analysis. 2019. vol. 97, pp. 220-226. 
[15] CHOKKALINGAM, B., RAJA, V., ANBURAJ, J., IMMANUAL, R., DHINESHKUMAR, M. Optimization of MicroAlloying Elements for Mechanical Properties in Normalized Cast Steel using Taguchi Technique. Archives of Foundry Engineering. 2017. vol. 17, pp. 171-177.

[16] MAKESHKUMAR, M., ANBURAJ, J. Study of combined effect of zirconium and titanium on microstructure and mechanical properties of micro-alloyed cast steels. Materials Research Express. 2019, vol. 6, art. $1065 \mathrm{D}$.

[17] LI, S., WEI, S., LI, D., LI, Y. Effects of heat treatment process and niobium addition on the microstructure and mechanical properties of low carbon steel weld metal. J. Mater. Sci. 2010. vol. 45, pp. 2390-2402.

[18] REITINGER, B., BERER, T., HELM, O., BURGHOLZER, P. Alteration of the Elastic Properties of Steel and Cast Iron Caused by Hardening. In Science, Technology and Applications: $1^{\text {st }}$ Int. Symp. Laser Ultrasonic. Montreal: SciTech, 2015, vol 6, pp. 6.

[19] GU, S., ZHANG, L., ZHANG, C., RUAN, J., ZHEN, Y. Modeling the effects of processing parameters on dynamic recrystallization behavior of deformed 38MnVS6 steel. J. Mater. Eng. Perform. 2015, vol. 24, pp. 1790-1798.

[20] OSTASZ, G., CZERWINSKA, K., PACANA, A. Quality management of aluminum pistons with the use of quality control points. Management Systems In Production Engineering. 2020, vol. 28, pp. 29-33.

[21] PACANA A., CZERWIŃSKA K., BEDNAROWA L., Discrepancies analysis of casts of diesel engine piston. Metalurgija. 2018. vol. 57, pp. 324-326.

[22] PACANA, A., SIWIEC, D., BEDNAROVA, L. Analysis of the incompatibility of the product with fluorescent method. Metalurgija. 2019. vol. 58, pp. 337-340.

[23] BORKOWSKI, S., ULEWICZ, R., SELEJDAK, J., KONSTANCIAK, M., KLIMECKA-TATAR, D. The use of $3 \times 3$ matrix to evaluation of ribbed wire manufacturing technology. In METAL 2012: 21st Int. Conf. on Metallurgy and Materials. Ostrava: TANGER, 2012, pp. 1722-1728.

[24] ULEWICZ, R., SZATANIAK, P., NOVY, F. Fatigue properties of wear resistant martensitic steel. In METAL 2014: 23rd Int. Conf. on Metallurgy and Materials. Ostrava, TANGER, 2014, pp. 784-789.

[25] LIPINSKI, T. The structure and mechanical properties of AI-7\%SiMg alloy treated with a homogeneous modifier. Solid State Phenomena. 2010. vol. 163, pp. 183-186.

[26] SZABRACKI, P., LIPINSKI, T. Influence of sigma phase precipitation on the intergranular corrosion resistance of X2CrNiMoN25-7-4 super duplex stainless steel. In METAL 2014: 23rd Int. Conf. on Metallurgy and Materials. Ostrava, TANGER, 2014, pp. 476-481.

[27] LIPINSKI, T. Double modification of AISi9Mg alloy with boron, titanium and strontium. Arch. Metall. Mater. 2015, vol. 60, pp. 2415-2419.

[28] ZORAWSKI, W., CHATYS, R., RADEK, N., BOROWIECKA-JAMROZEK, J. Plasma-sprayed composite coatings with reduced friction coefficient. Surface \& Coatings Technology. 2008. vol. 202, pp. 4578-4582.

[29] DUDEK, A. Surface properties in titanium with hydroxyapatite coating. Optica Applicata. 2009. vol. 39, pp.825-831.

[30] DUDEK, A., WLODARCZYK, R. Structure and Properties of Bioceramics Layers Used for Implant Coatings. Solid State Phenom. 2010, vol. 165, pp. 31-36.

[31] DUDEK, A. Investigations of microstructure and properties in bioceramic coatings used in medicine. Arch. Metall Mater. 2011. vol. 56, pp. 135-140.

[32] INGALDI, M. Management of the packaging waste in companies in Poland. In Int. Multidisciplinary Sci. GeoConference Surveying Geology and Mining Ecology Management SGEM. Vol.3, 2015, pp. 385-392.

[33] ULEWICZ, R., BLASKOVA, M. Sustainable development and knowledge management from the stakeholders' point of view. Polish Journal of Management Studies. 2018. vol. 18, pp. 363-374.

[34] PACANA, A., PASTERNAK-MALICKA, M., ZAWADA. M. and RADON-CHOLEWA, A. Decision support in the production of packaging films by cost-quality analysis. Przemysl Chemiczny. 2016. vol. 95, pp. 1042-1044. 